\title{
Pengaruh Motivasi Kerja Dan Disiplin Kerja Terhadap Kinerja Karyawan Pada PT Pegadaian (Persero) Cabang Nganjuk
}

\author{
Kartika Dwi Arisanti; Ariadi Santoso; Siti Wahyuni \\ Fakultas Ekonomi - Universitas Kadiri \\ E-mail : ariadi_santoso@unik-kediri.ac.id
}

\begin{abstract}
The purpose of this study was to determine the effect of work motivation and work discipline on employee performance at PT. Pegadaian (Persero). In this study, the population is all employees of PT. Pegadaian (Persero) Nganjuk Branch totaling 32 employees with sampling using saturated sampling techniques. Based on the results of the study, the regression equation is obtained as follows: $\mathrm{Y}=3.838+1.451 \mathrm{X} 1+$ $0.063 \mathrm{X} 2+\mathrm{e}$ can be stated Work Motivation variable (X1) and Work Discipline variable (X2) give a positive influence on the Employee Performance of PT. Pegadaian (Persero) Nganjuk Branch. The results showed that partially the work motivation variable had a significant effect on employee performance, while the work discipline had no significant effect on employee performance. Simultaneously, the variables of work motivation and work discipline have a significant effect on employee performance at PT. Pegadaian (Persero) Nganjuk Branch. The results of the analysis of the coefficient of determination are 0.483 or $48.3 \%$, which means that the contribution of work motivation and work discipline variables to performance is $48.3 \%$, while the rest is influenced by other factors outside of this regression model.
\end{abstract}

Keywords: Work Motivation, Work Discipline, Performance

\section{ABSTRAK}

Tujuan dilaksanakannya penelitian ini adalah untuk mengetahui pengaruh motivasi kerja dan disiplin kerja terhadap kinerja karyawan pada PT. Pegadaian (Persero). Dalam penelitian ini, populasi adalah seluruh karyawan PT. Pegadaian (Persero) Cabang Nganjuk yang berjumlah 32 karyawan dengan pengambilan sampel menggunakan teknik sampling jenuh. Berdasarkan hasil penelitian, diperoleh persamaan regresi sebagai berikut: $\mathrm{Y}=3,838+1,451 \mathrm{X}_{1}+0,063 \mathrm{X}_{2}+\mathrm{e}$ dapat dinyatakan variabel Motivasi Kerja $\left(\mathrm{X}_{1}\right)$ dan variabel Disiplin Kerja $\left(\mathrm{X}_{2}\right)$ memberikan pengaruh positif terhadap Kinerja Karyawan PT. Pegadaian (Persero) Cabang Nganjuk. Hasil penelitian menunjukkan bahwa secara parsial variabel motivasi kerja berpengaruh signifikan terhadap kinerja karyawan, sedangkan disiplin kerja berpengaruh tidak signifikan terhadap kinerja karyawan. Secara simultan, variabel motivasi kerja dan disiplin kerja berpengaruh signifikan terhadap kinerja karyawan pada PT. Pegadaian (Persero) Cabang Nganjuk. Hasil analisis koefisien determinasi diperoleh 0,483 atau 48,3\%, yang artinya kontribusi variabel motivasi kerja dan disiplin kerja terhadap kinerja sebesar 48,3\%, sedangkan sisanya dipengaruhi oleh faktor lain di luar model regresi ini.

Kata kunci : Motivasi Kerja, Disiplin Kerja, Kinerja 


\section{PENDAHULUAN}

Salah satu faktor penting yang menentukan kemajuan atau tidaknya suatu organisasi terletak pada kualitas sumber daya manusianya. Setiap organisasi selalu berusaha mendapatkan sumber daya manusia yang dapat membantu tercapainya tujuan organisasi tersebut. Keberhasilan suatu perusahaan sangat ditentukan oleh kesuksesan perusahaan dalam mengelola sumber daya manusia yang dimiliki dalam tercapainya tujuan suatu perusahaan (Mariani, 2016). Motivasi berpengaruh terhadap kepuasan kerja dosen, motivasi juga berpengaruh terhadap prestasi dosen dan kepuasan memberikan pengaruh terhadap prestasi dosen (Yogi yunanto, 2017)

Meningkatkan kinerja karyawan adalah salah satu usaha yang akan selalu dilakukan setiap perusahaan untuk tercapainya suatu tujuan. SDM yang berkualitas memiliki dampak besar dalam perkembangan perusahaan. Sedangkan meningkatkan sumber daya manusia yang berkualitas tinggi membutuhkan metode yang berbeda dalam suatu perusahaan. Motivasi kerja dan disiplin kerja adalah beberapa metode tersebut (Hartanti, 2016).

Menurut Siagian dalam (Wijaya, 2016) bahwa kinerja karyawan dipengaruhi oleh beberapa faktor yang termasuk adalah gaji, lingkungan kerja, budaya organisasi, kepemimpinan dan motivasi kerja (Rahayu \& Ruhamak, 2018). Faktor internal dan eksternal juga sangat mempengaruhi kinerja karyawan. Faktor internal termasuk gaya kepemimpinan, kemampuan berdasarkan pengetahuan dan keterampilan, kepuasan kerja, dan juga motivasi kerja. Sedangkan faktor eksternal termasuk lingkungan kerja dan situasi kerja.Secara bersama-sama kualitas pelayanan dan disiplin kerja karyawan berpengaruh secara positif dan signifikan terhadap kepuasan pasien (Yunanto, 2016)

Dalam penelitian ini, penulis meneliti motivasi kerja dan disiplin kerja. Apabila motivasi kerja baik dan disiplin kerja juga baik, maka kinerja yang dihasilkan pun akan baik juga. Menurut Wursanto dalam (Ashadi, 2011) menyatakan bahwa motivasi adalah dorongan, keinginan dan kekuatan penggerak yang berasal dari diri manusia untuk melakukan sesuatu. Sedangkan disiplin adalah kepatuhan pada aturan atau perintah yang ditetapkan oleh organisasi (Widayaningtyas, 2016).

PT. Pegadaian (Persero) adalah Badan Usaha Milik Negara (BUMN) di Indonesia yang usahanya bergerak dalam bidang pinjaman kepada masyarakat atau hukum gadai. Untuk mencapai tujuannya tersebut, PT. Pegadaian (Persero) bersaing 
dengan perusahaan sejenis lainnya seperti : FIF, OTO, dan ADIRA finance. Oleh sebab itu PT. Pegadaian (Persero) diharapkan semaksimal mungkin untuk dapat memiliki sumber daya manusia atau staf dan sumber daya bukan manusia yang berkualitas. Berbagai jenis program intern dan ekstern telah dilakukan oleh PT. Pegadaian (Persero), yang disesuaikan dengan kebutuhan dalam rangka untuk meningkatkan profesionalisme.

Menurut Sunarso selaku Direktur Utama PT. Pegadaian (Persero), kinerja keuangan perusahaan pada tahun 2018 diperkirakan akan terus tumbuh positif seiring karena prospek ekonomi nasional terus tumbuh sebesar 5,4 persen. PT. Pegadaian (Persero) menargetkan laba bersih sebesar Rp 2,7 triliun pada tahun 2018 (economy.okezone.com). Berdasarkan data tersebut, PT. Pegadaian (Persero) bisa mencapai hasil maksimal dengan meningkatkan kualitas dan kuantitas sumber daya yang dimiliki demi tercapainya tujuan perusahaan.

Pada prinsipnya telah ada motivasi dan disiplin kerja yang baik pada PT. Pegadaian Cabang Nganjuk, akan tetapi masih ditemukan adanya presentasi yang fluktuatif. Berdasarkan survei dari beberapa karyawan melalui wawancara sekilas tentang motivasi kerja dan disiplin kerja yang dirasakan oleh karyawan. PT. Pegadaian Cabang Nganjuk saat ini, diperoleh fenomena yang terjadi di perusahaan, yaitu: gairah kerja karyawan relatif rendah. Hal ini dapat dilihat dari jumlah antrian nasabah yang sangat panjang karena lamanya pelayanan yang diberikan dan kurangnya kualitas pelayanan yang baik. Pengukuran antrian nasabah diukur secara relatif, yang berarti juga meminta tanggapan pada nasabah yang sedang mengantri dan pada saat pengukuran. Dan masih ada kurangnya pelatihan bagi karyawan sehingga saat proses mutasi atau promosi, ada karyawan yang belum mengerti atau memahami tugas masingmasing. Serta masih ditemukan karyawan yang tidak pergi bekerja ketika ada hari "kecepit". Adapun yang menjadi tujuan dalam penelitian ini adalah:

1. Mengetahui pengaruh motivasi kerja terhadap kinerja karyawan pada PT. Pegadaian (Persero) Cabang Nganjuk.

2. Mengetahui pengaruh disiplin kerja terhadap kinerja karyawan pada

PT. Pegadaian (Persero) Cabang Nganjuk.

3. Mengetahui pengaruh motivasi kerja dan disiplin kerja terhadap kinerja karyawan pada PT. Pegadaian (Persero) Cabang Nganjuk. 


\section{TINJAUAN PUSTAKA}

\section{Motivasi Kerja}

Menurut beberapa ahli, motivasi didefinisikan sebagai berikut: (Hasibuan, 2009:141) menyatakan bahwa motivasi kerja adalah hal yang menyebabkan, menyalurkan, dan mendukung perilaku manusia, supaya mau bekerja giat dan antusias mencapai hasil yang optimal. Sedangkan menurut (Notoatmodjo, 2009:115) Motivasi kerja adalah suatu alasan (reasoning) seseorang untuk bertindak dalam rangka memenuhi kebutuhan hidupnya.

Dari definisi-definisi motivasi menurut beberapa ahli di atas dapat disimpulkan bahwa motivasi kerja adalah suatu kondisi yang mendorong dan menggerakkan seseorang dari dalam diri sendiri atau dari luar dirinya dengan keterampilan dan kemampuan yang dimilikya untuk melakukan suatu kegiatan supaya mendapatkan hasil kerja yang baik dan tercapainya suatu tujuan.

Motivasi sebenarnya memiliki beberapa teori dari beberapa pendapat tokoh, dan dalam penelitian ini, indikator yang digunakan untuk pengukuran motivasi kerja adalah teori motivasi yang sangat terkenal yaitu hierarki teori kebutuhan (hierarchical of needs thry) yang dikemukakan oleh Abraham Maslow dalam (Robbins, 2008:223) bahwa pada setiap diri manusia itu terdiri atas lima kebutuhan, yaitu:

1. Kebutuhan Fisiologis (Physiological-need)

Kebutuhan fisiologis merupakan kebutuhan paling dasar dan kebutuhan pokok manusia untuk bertahan hidup yang meliputi sandang, pangan, papan dan kesejahteraan individu.

2. Kebutuhan Rasa Aman (Safety Needs)

Kebutuhan rasa aman merupakan kebutuhan yang tidak hanya diartikan dalam arti keamanan fisik saja tetapi juga keamanan psikologis serta perlakuan yang adil dalam pekerjaan.

3. Kebutuhan Sosial (Social Needs)

Apabila kebutuhan rasa aman telah terpuaskan, maka muncul kebutuhan ketiga yaitu kebutuhan sosial. Sebagai makhluk sosial, manusia tidak dapat memenuhi kebutuhannya sendiri untuk berinteraksi dengan orang lain.

4. Kebutuhan Penghargaan (Esteem-need) 
Kebutuhan penghargaan diri meliputi kebutuhan akan harga diri, kebutuhan dihormati dan dihargai orang lain, pengakuan atas kemampuan dan keahlian seseorang serta efektifitas kerja seseorang.

5. Kebutuhan Aktualisasi Diri (self-actualization need)

Kebutuhan aktualisasi diri merupakan kebutuhan yang berkaitan dengan proses pengembangan potensi yang sebenarnya untuk menunjukkan kemampuan, keahlian dan potensi yang dimiliki seseorang.

\section{Disiplin Kerja}

Definisi disiplin kerja menurut para ahli diantaranya yaitu menurut (Mangkunegara, 2013), disiplin kerja didefinisikan sebagai pelaksanaan manajemen yang bertujuan untuk memperteguh pedoman-pedoman organisasi. Sedangkan Menurut (Rivai, 2011), disiplin kerja merupakan suatu hal dipergunakan manajer untuk berkomunikasi dengan karyawan supaya mereka bersedia mengubah perilaku dan untuk meningkatkan kesadaran dan kesediaan seseorang dalam memenuhi segala peraturan perusahaan.

Dari beberapa definisi yang dikemukakan oleh beberapa ahli dapat disimpulkan bahwa disiplin kerja adalah suatu sikap, tingkah laku, dan perbuatan yang sesuai dengan peraturan baik tertulis maupun tidak tertulis dan apabila melanggar akan mendapatkan sanksi atau hukuman atas pelanggarannya.

Terdapat beberapa indikator yang mempengaruhi tingkat kedisiplinan karyawan suatu organisasi. (Singodimejo dalam Sutrisno, 2016:94)

1. Taat terhadap aturan waktu

Taat terhadap aturan waktu dapat dilihat dari jam masuk dan pulang kerja serta jam istirahat yang tepat sesuai dengan peraturan dalam perusahaan.

2. Taat terhadap peraturan perusahaan

Taat terhadap peraturan perusahaan seperti peraturan dasar tentang cara berpakaian dan juga cara bertingkah laku dalam pekerjaan.

3. Taat terhadap aturan perilaku dalam pekerjaan.

Taat terhadap aturan perilaku ditunjukkan dengan cara melakukan pekerjaanpekerjaan sesuai dengan jabatan, tugas, tanggung jawab dan juga cara berhubungan dengan unit kerja lain.

4. Taat terhadap peraturan lainnya 
Peraturan lainnya seperti aturan tentang apa yang boleh dilakukan dan yang tidak boleh dilakukan oleh para karyawan dalam suatu perusahaan.

\section{Kinerja}

Menurut (Ramdhani, 2011:18), kinerja merupakan kesediaan seseorang atau suatu kelompok untuk melakukan kegiatan dan menyempurnakannya sesuai dengan tanggung jawabnya dengan hasil seperti yang diharapkan. Kinerja karyawan juga dapat diartikan hasil kerja secara kualitas dan kuantitas yang dicapai oleh karyawan dalam melaksanakan tugasnya sesuai dengan tanggung jawab yang diberikan kepadanya (Mangkunegara, 2014).

Dari dua pengertian kinerja tersebut, dapat disimpulkan bahwa kinerja merupakan hasil pencapaian seseorang atau suatu kelompok dalam menyelesaikan tugas dan tanggung jawab yang diberikan.

Terdapat delapan indikator pengukuran kinerja menurut (Ramdhani, 2011:27) yang termasuk juga dalam teori Dessler, yaitu:

1. Pemahaman Pekerjaan/Kompetensi

2. Kuantitas/Kualitas Kerja

3. Perencanaan/Organisasi

4. Komitmen/Inisiatif

5. Penyelesaian Masalah/Kreatifitas

6. Kerjasama dan Kerja Tim

7. Kemampuan berhubungan dengan orang lain

8. Komunikasi (lisan dan tulisan)

\section{Hipotesis}

Berdasarkan latar belakang masalah dan teori yang telah dibahas maka dapat diajukan hipotesis sebagai berikut :

$\mathrm{H}_{1}$ : Motivasi Kerja berpengaruh secara signifikan terhadap kinerja karyawan pada PT. Pegadaian (Persero) Cabang Nganjuk

$\mathrm{H}_{2}$ : Disiplin Kerja berpengaruh secara signifikan terhadap kinerja karyawan pada PT. Pegadaian (Persero) Cabang Nganjuk

$\mathrm{H}_{3}$ : Terdapat pengaruh secara simultan motivasi kerja dan disiplin kerja terhadap kinerja karyawan pada PT. Pegadaian (Persero) Cabang Nganjuk 


\section{METODE PENELITIAN}

\section{Populasi Dan Sampel Penelitian}

Populasi pada penelitian ini adalah karyawan yang ada di PT. Pegadaian (Persero) Cabang Nganjuk yang berjumlah 32 karyawan. Dengan populasi yang relatif kecil, peneliti menggunakan sampling jenuh sebagai teknik pengambilan sampel, yaitu teknik penentuan sampel bila keseluruhan anggota populasi diambil sebagai sampel, sebanyak 32 responden.

\section{Variabel Penelitian, Cara Pengukuran Dan Definisi Operasional}

Variabel yang akan dianalisis dalam penelitian ini dapat dikelompokkan menjadi dua yaitu

1. Variabel bebas (independent)

a. Motivasi kerja $\left(\mathrm{X}_{1}\right)$

Indikatornya adalah :

- Fisiologis

- Keamanan

- Sosial

- Penghargaan

- Aktualisasi (Robbins:2008)

b. Disiplin kerja $\left(\mathrm{X}_{2}\right)$

Indikatornya adalah :

- Taat terhadap aturan waktu

- Taat terhadap peraturan perusahaan

- Taat terhadap aturan perilaku dalam pekerjaan

- Taat terhadap peraturan lainnya (Singodimejo dalam Sutrisno, 2016:94)

2. Variabel terikat (dependent) yaitu variabel Kinerja Karyawan (Y).

Indikatornya adalah :

- Pemahaman Pekerjaan/kompetensi

- Kuantitas/kualitas kerja

- Perencanaan/organisasi

- Komitmen/inisiatif 
- Penyelesaian Masalah/kreatifitas

- Kerjasama dan kerja tim

- Kemampuan berhubungan dengan orang lain

- Komunikasi (lisan dan tulisan) (Ramdhani, 2011:27)

Cara pengukurannya menggunakan kuesioner dan skala penilaian menggunakan skala Likert dengan memberikan penilaian atas jawaban sebagai berikut:

- SS : Sangat Setuju $\quad: 5$

$-\mathrm{S} \quad$ : Setuju $\quad: 4$

- KS : Kurang Setuju $\quad: 3$

- TS : Tidak Setuju : :2

- $\quad$ STS : Sangat Tidak Setuju $\quad: 1$

\section{Metode Pengumpulan Data}

Beberapa teknik yang digunakan untuk memperoleh data dalam penelitian ini adalah sebagai berikut :

1. Interview (wawancara)

Menurut (Sugiyono, 2013:317) wawancara digunakan sebagai teknik pengumpulan data, apabila peneliti ingin melakukan studi pendahuluan dan juga untuk mengetahui hal-hal dari responden yang lebih mendalam.

2. Kuesioner (Angket)

Menurut (Sugiyono, 2016:162), angket atau kuesioner merupakan teknik pengumpulan data yang dilakukan dengan cara memberi seperangkat pertanyaan atau pernyataan tertulis kepada responden untuk dijawabnya.

3. Studi Kepustakaan

Studi kepustakaan yaitu metode pengumpulan data yang diperoleh dari buku-buku, jurnal-jurnal penelitian terdahulu dan literatur lain yang berhubungan dengan materi penelitian.

\section{Metode Analisis Data}

Metode analisis data yang digunakan peneliti adalah analisis kuantitatif, antara lain :

1. Uji Validitas dan Uji Reliabilitas 
Uji validitas digunakan untuk mengetahui tingkat kevalidan dari instrumen (kuesioner) yang digunakan dalam pengumpulan data. Suatu kuesioner dikatakan valid jika pertanyaan pada kuesioner mampu untuk mengungkapkan sesuatu yang akan diukur oleh kuesioner tersebut (Ghozali, 2011:97).

Dasar pengambilan keputusan yang digunakan untuk menguji validitas butir angket adalah :

- Jika $r_{\text {hitung positif dan }} r_{\text {hitung }}>r_{\text {tabel }}$ maka variabel tersebut valid.

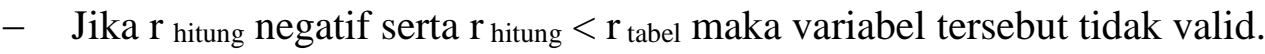

Sedangkan uji Reliabilitas digunakan untuk menguji sejauh mana alat ukur dapat dipercaya. Dengan kriteria pengujian menurut (Arikunto, 2010:85):

- Jika $\mathrm{r}$ hitung $>\mathrm{r}$ tabel dengan taraf signifikan 0,01, maka alat ukur tersebut dinyatakan reliabel, dan

- sebaliknya apabila $\mathrm{r}$ hitung $<\mathrm{r}$ tabel, maka alat ukur tersebut dinyatakan tidak reliabel.

2. Uji Asumsi Klasik

a. Uji Normalitas

Uji normalitas bertujuan untuk menguji apakah dalam model regresi, variabel penganggu atau residual memiliki distribusi normal, dengan menggunakan Uji statistik non-parametrik Kolmogrov-Smirnov (K-S) yang dilakukan dengan membuat hipotesis :

Ho : data residual berdistribusi normal

$\mathrm{Ha}:$ data residual tidak berdistribusi normal

Pengujian yang dapat menunjukkan data normal yang diperoleh apabila nilai signifikasinya adalah $>0,01$.

b. Uji Multikolinearitas

Uji multikolinearitas bertujuan untuk menguji apakah model regresi ditemukan adanya kolerasi antar variabel bebas (independen) dengan kriteria sebagai berikut :

a. Mempunyai angka Tolerance $\leq 0,10$

b. Mempunyai nilai VIF $\geq 10$

c. Uji Heteroskedastisitas

Uji heteroskedastisitas bertujuan menguji apakah dalam model regresi terjadi ketidaksamaan variance dari residual satu pengamatan ke pengamatan lain. Untuk mendeteksi ada atau tidaknya Heteroskedastisitas adalah dengan melihat 
Grafik Plot, jika tidak ada pola yang jelas serta titik-titik menyebar di atas dan di bawah angka 0 pada sumbu Y, maka tidak terjadi Heteroskedastisitas.

3. Analisis Regresi Linier Berganda

Analisis regresi berganda digunakan untuk mengetahui pengaruh variabel bebas terhadap variabel tidak bebas (terikat), dengan rumus :

$$
\mathbf{Y}=\mathbf{a}+\mathbf{b}_{1} \mathbf{X}_{1}+\mathbf{b}_{2} \mathbf{X}_{2}+\mathbf{e}
$$

Dimana:

$\begin{array}{ll}\mathrm{Y} & : \text { Kinerja Karyawan } \\ \mathrm{a} & : \text { Konstanta } \\ \mathrm{b}_{1}, \mathrm{~b}_{2} & : \text { Koefisien Regresi } \\ \mathrm{X}_{1} & : \text { Motivasi Kerja } \\ \mathrm{X}_{2} & : \text { Disiplin Kerja } \\ \mathrm{e} & : \text { Kontanta }\end{array}$

4. Uji Hipotesis

a. Pengujian secara Parsial (Uji t)

Uji t digunakan untuk membuktikan apakah indikator dari motivasi kerja secara parsial berpengaruh signifikan terhadap variabel kinerja karyawan. Kriteria pengambilan keputusan yaitu :

- Jika nilai signifikan $\mathrm{t}$ hitung $>\mathrm{t}$ tabel, maka variabel bebas berpengaruh signifikan terhadap variabel terikat.

- Jika nilai signifikan $\mathrm{t}$ hitung $<\mathrm{t}$ tabel, maka variabel bebas tidak berpengaruh signifikan terhadap variabel terikat.

b. Pengujian secara Simultan (Uji F)

Pengujian hipotesis secara simultan digunakan untuk mengetahui variabel bebas (X) berpengaruh signifikan terhadap variabel terikat (Y). Kriteria pengambilan keputusannya yaitu :

- Jika $\mathrm{F}$ hitung $>\mathrm{F}$ tabel, maka variabel bebas secara simultan berpengaruh signifikan terhadap variabel terikat.

- Jika nilai $\mathrm{F}$ hitung $<\mathrm{F}$ tabel, maka variabel bebas secara simultan tidak berpengaruh signifikan terhadap variabel terikat.

c. Koefisien Determinasi $\left(\mathrm{R}^{2}\right)$

Koefisien determinasi $\left(\mathrm{R}^{2}\right)$ digunakan untuk mengukur besarnya kontribusi variabel bebas secara bersama-sama terhadap variabel terikatnya. Jika $\left(\mathrm{R}^{2}\right)$ yang 
diperoleh mendekati 1 (satu) maka dapat dikatakan semakin kuat model tersebut menerangkan hubungan variabel bebas terhadap variabel terikat.

\section{HASIL PENELITIAN DAN PEMBAHASAN}

Penelitian ini bertujuan untuk mengetahui pengaruh motivasi kerja dan disiplin kerja terhadap kinerja karyawan di PT. Pegadaian (Persero) Cabang Nganjuk yang berlokasi di Jalan Supriyadi No.16 Kauman Kabupaten Nganjuk.

\section{Hasil Analisis Data}

\section{Uji Validitas Dan Reliabilitas}

Tabel 1 : Hasil Uji Validitas

\begin{tabular}{|c|c|c|c|c|}
\hline No. & Pertanyaan & $\mathbf{r}_{\text {hitung }}$ & $\mathbf{r}_{\text {tabel }}$ & Validitas \\
\hline \multicolumn{5}{|c|}{ Variabel Motivasi Kerja (X1) } \\
\hline 1. & $\mathrm{X} 1.1$ & 0,578 & 0,449 & Valid \\
\hline 2. & $\mathrm{X} 1.2$ & 0,674 & 0,449 & Valid \\
\hline 3. & $\mathrm{X} 1.3$ & 0,521 & 0,449 & Valid \\
\hline 4. & $\mathrm{X} 1.4$ & 0,596 & 0,449 & Valid \\
\hline 5. & $\mathrm{X} 1.5$ & 0,651 & 0,449 & Valid \\
\hline \multicolumn{5}{|c|}{ Variabel Disiplin Kerja (X2) } \\
\hline 1. & $\mathrm{X} 2.1$ & 0,695 & 0,449 & Valid \\
\hline 2. & $\mathrm{X} 2.2$ & 0,620 & 0,449 & Valid \\
\hline 3. & $\mathrm{X} 2.3$ & 0,649 & 0,449 & Valid \\
\hline 4. & $\mathrm{X} 2.4$ & 0,568 & 0,449 & Valid \\
\hline \multicolumn{5}{|c|}{ Variabel Kinerja Karyawan (Y) } \\
\hline 1. & Y1 & 0,656 & 0,449 & Valid \\
\hline 2. & Y2 & 0,706 & 0,449 & Valid \\
\hline 3. & Y3 & 0,613 & 0,449 & Valid \\
\hline 4. & Y4 & 0.780 & 0,449 & Valid \\
\hline 5. & Y5 & 0,613 & 0,449 & Valid \\
\hline 6. & Y6 & 0,780 & 0,449 & Valid \\
\hline 7. & Y7 & 0,611 & 0,449 & Valid \\
\hline 8. & Y8 & 0,780 & 0,449 & Valid \\
\hline
\end{tabular}

Sumber : Data Primer Yang Diolah Peneliti (2019)

Tabel 2 : Hasil Uji Reliabilitas

\begin{tabular}{|c|c|c|}
\hline Variabel & Cronbach'sAlpha & Keterangan \\
\hline Motivasi Kerja (X1) & 0,734 & Reliabel \\
\hline Disiplin Kerja (X2) & 0,739 & Reliabel \\
\hline Kinerja (Y) & 0,769 & Reliabel \\
\hline
\end{tabular}

Sumber : Data Primer Yang Diolah Peneliti (2019)

\section{Uji Asumsi Klasik}

\section{a. Uji Normalitas}

Tabel 3 : Hasil Uji Normalitas One-Sample Kolmogorov-Smirnov 
One-Sample Kolmogorov-Smirnov Test

\begin{tabular}{|c|c|c|}
\hline & & Unstandardized Residual \\
\hline \multicolumn{2}{|l|}{$\mathrm{N}$} & 32 \\
\hline \multirow[t]{2}{*}{ Normal Parameters ${ }^{\mathrm{a}, \mathrm{b}}$} & Mean &, 0000000 \\
\hline & Std. Deviation & 3,27682355 \\
\hline \multirow[t]{3}{*}{ Most Extreme Differences } & Absolute &, 144 \\
\hline & Positive & ,089 \\
\hline & Negative &,- 144 \\
\hline \multicolumn{2}{|l|}{ Test Statistic } & 144 \\
\hline \multicolumn{2}{|l|}{ Asymp. Sig. (2-tailed) } & $090^{\mathrm{c}}$ \\
\hline \multicolumn{3}{|l|}{ a. Test distribution is Normal. } \\
\hline \multicolumn{3}{|l|}{ b. Calculated from data. } \\
\hline
\end{tabular}

Sumber : Data Primer Yang Diolah Peneliti (2019)

Berdasarkan output di atas dapat dilihat dari nilai Asymp.Sig.(2-tailed)

sebesar 0,090 lebih besar dari $\alpha=0,01$, maka dapat disimpulkan bahwa data tersebut berdistribusi normal.

\section{b. Hasil Uji Multikolinearitas}

Tabel 4 : Uji Multikolinieritas

\begin{tabular}{|c|c|c|c|}
\hline Variabel & Tolerance & VIF & Hasil \\
\hline $\mathrm{X} 1$ & 0,953 & 1,049 & Tidak terjadi multikolinearitas \\
\hline $\mathrm{X} 2$ & 0,953 & 1,049 & Tidak terjadi multikolinearitas \\
\hline
\end{tabular}

Sumber : Data Primer Yang Diolah Peneliti (2019)

Pada Tabel 4 nilai VIF untuk variabel $\mathrm{X}_{1}$ dan $\mathrm{X}_{2}$ adalah 1,049. Karena nilai VIF dari kedua variabel tidak ada yang lebih besar dari 10 maka dapat dikatakan tidak terjadi multikolinieritas pada kedua variabel bebas tersebut.

\section{c. Hasil Uji Heteroskedastisitas}

\section{Gambar 1 : Hasil Uji Heteroskedastisitas}

scalteiplot Dependent Verloble: $Y$

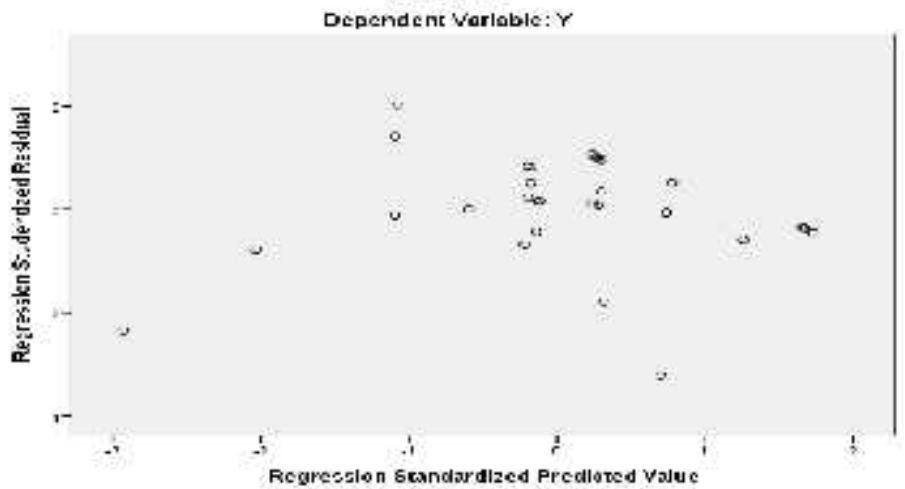

Sumber : Data Primer Yang Diolah Peneliti (2019) 
Dari Gambar 1 di atas terlihat bahwa sebaran titik tidak membentuk suatu pola/alur tertentu, sehingga dapat disimpulkan tidak terjadi heteroskedastisitas.

\section{Hasil Regresi Linier Berganda}

Tabel 5 : Hasil Analisis Regresi Linier Berganda Coefficients $^{\mathrm{a}}$

\begin{tabular}{|c|c|c|c|c|c|}
\hline \multirow[b]{2}{*}{ Model } & \multicolumn{2}{|c|}{ Unstandardized Coefficients } & \multirow{2}{*}{$\frac{\text { Standardized Coefficients }}{\text { Beta }}$} & \multirow[b]{2}{*}{$\mathrm{t}$} & \multirow[b]{2}{*}{ Sig. } \\
\hline & $\mathrm{B}$ & Std. Error & & & \\
\hline $1 \quad$ (Constant) & 3,838 & 7,976 & & ,481 &, 634 \\
\hline $\mathrm{X} 1$ & 1,451 & 288 & 690 & 5,043 & ,000 \\
\hline $\mathrm{X} 2$ &, 063 & ,398 & 021 &, 157 &, 876 \\
\hline
\end{tabular}

a. Dependent Variable: Y

Sumber : Data Primer Yang Diolah Peneliti (2019)

Berdasarkan tabel 5 diperoleh persamaan hasil analisis regresi linier berganda sebagai berikut:

$$
Y=3,838+1,451 X_{1}+0,063 X_{2}+e
$$

Dari persamaan regresi linier berganda di atas dapat diartikan variabel Motivasi Kerja $\left(\mathrm{X}_{1}\right)$ dan variabel Disiplin Kerja $\left(\mathrm{X}_{2}\right)$ memberikan pengaruh positif terhadap Kinerja Karyawan PT. Pegadaian (Persero) Cabang Nganjuk.

\section{Uji Hipotesis}

\section{a. Pengujian secara Parsial (Uji t)}

- Variabel Motivasi Kerja

Dari hasil perhitungan didapatkan nilai $\mathrm{t}_{\text {hitung }}$ sebesar 5,043 lebih dari dari $\mathrm{t}$ tabel adalah 2,756 dengan nilai signifikan $0,000<0,01$. Maka dapat dikatakan bahwa motivasi kerja berpengaruh signifikan terhadap kinerja karyawan. Artinya, $\mathrm{H}_{1}$ diterima dan $\mathrm{H}_{0}$ ditolak.

- Variabel Disiplin Kerja

Dari hasil perhitungan output di atas dapat disimpulkan bahwa nilai $\quad \mathrm{t}$ hitung sebesar 0,157 kurang dari nilai $\mathrm{t}$ tabel adalah 2,756 dengan nilai signifikan 0,876 >0,01. Maka dapat dikatakan bahwa tidak terdapat pengaruh signifikan terhadap kinerja karyawan yang artinya $\mathrm{H}_{0}$ diterima dan $\mathrm{H}_{2}$ ditolak. 


\section{b. Pengujian secara Simultan (Uji F)}

Tabel 6 : Hasil Uji Secara Simultan (Uji F)

ANOVA $^{\mathrm{a}}$

\begin{tabular}{|c|c|c|c|c|c|}
\hline Model & Sum of Squares & $\overline{d f}$ & Mean Square & $\bar{F}$ & Sig. \\
\hline $1 \quad$ Regression & 310,635 & 2 & 155,318 & 13,532 &, $000^{\mathrm{b}}$ \\
\hline Residual & 332,865 & 29 & 11,478 & & \\
\hline Total & 643,500 & 31 & & & \\
\hline
\end{tabular}

a. Dependent Variable: Y

b. Predictors: (Constant), X2, X1

Sumber : Data Primer Yang Diolah Peneliti (2019)

Berdasarkan pada tabel 6 bahwa hasil $\mathrm{F}_{\text {hitung }}$ menunjukkan nilai 13,532

lebih besar dari $\mathrm{F}$ tabel yaitu 3,32 sehingga dapat disimpulkan bahwa $\mathrm{H}_{3}$ diterima dan $\mathrm{H}_{0}$ ditolak yang menyatakan "terdapat pengaruh secara simultan antara motivasi kerja dan disiplin kerja terhadap kinerja karyawan pada PT. Pegadaian Cabang Nganjuk".

c. Hasil Uji Koefisien Determinasi $\left(\mathbf{R}^{2}\right)$

Tabel 7 : Hasil Analisis Koefisien Determinasi $\left(\mathbf{R}^{2}\right)$ Model Summary

\begin{tabular}{|l|c|r|r|r|}
\hline Model & R & R Square & Adjusted R Square & Std. Error of the Estimate \\
\hline 1 &, $695^{\mathrm{a}}$ &, 483 &, 447 & 3,38793 \\
\hline
\end{tabular}

a. Predictors: (Constant), X2, X1

b. Dependent Variable: Y

Sumber : Data Primer Yang Diolah Peneliti (2019)

Berdasarkan tabel di atas, diketahui nilai koefisien determinasi atau $\mathrm{R}$ Square adalah sebesar 0,483 , yang berarti bahwa variabel motivasi kerja $\left(\mathrm{X}_{1}\right)$ dan variabel disiplin kerja $\left(\mathrm{X}_{2}\right)$ berpengaruh terhadap variabel kinerja karyawan (Y) sebesar 48,3\%. Sedangkan sisanya 51,7\% dipengaruhi oleh variabel lain di luar persamaan regresi ini atau variabel yang tidak diteliti.

\section{Pembahasan}

Hasil analisis di atas, memberikan beberapa informasi secara rinci tentang hasil penelitian serta bagaimana pengaruh masing-masing variabel terhadap variabel lainnya.

1. Pengaruh Motivasi Kerja $\left(\mathrm{X}_{1}\right)$ terhadap Kinerja Karyawan (Y) PT. Pegadaian Cabang Nganjuk 
Berdasarkan hasil analisis data diketahui bahwa nilai signifikansi uji t sebesar 5,043 lebih dari $\mathrm{t}$ tabel adalah 2,756 dengan nilai signifikan 0,000<0,01. Maka dapat dikatakan variabel motivasi kerja berpengaruh signifikan terhadap kinerja karyawan pada PT. Pegadaian Cabang Nganjuk. Artinya, $\mathrm{H}_{0}$ ditolak dan $\mathrm{H}_{1}$ diterima.

Hasil tersebut selaras dengan penelitian dari (Nanang, 2016), dalam skripsi yang berjudul "Pengaruh Motivasi dan Disiplin Kerja terhadap Kinerja Karyawan Outsourcing (Studi pada Perusahaan Penyedia Jasa Outsourcing PT. ASH Cabang Madiun)" menunjukkan bahwa variabel motivasi berpengaruh positif dan signifikan terhadap kinerja karyawan. Hasil penelitian ini didukung oleh (Rivai, 2008) berpendapat pada dasarnya motivasi dapat memacu karyawan untuk bekerja keras sehingga dapat mencapai tujuannya, dengan hal demikian akan meningkatkan kinerja karyawan sehingga berpengaruh terhadap pencapaian tujuan perusahaan.

2. Pengaruh Disiplin Kerja $\left(\mathrm{X}_{2}\right)$ terhadap Kinerja Karyawan (Y) PT. Pegadaian Cabang Nganjuk

Dari hasil perhitungan output di atas dapat disimpulkan bahwa nilai hitung sebesar 0,157 kurang dari nilai $\mathrm{t}$ tabel adalah 2,756 dengan nilai signifikansi $0,876>0,01$. Maka dapat dikatakan bahwa disiplin kerja berpengaruh tidak signifikan terhadap kinerja karyawan pada PT. Pegadaian Cabang Nganjuk yang artinya $\mathrm{H}_{0}$ diterima dan $\mathrm{H}_{2}$ ditolak.

Hasil penelitian ini berbeda dengan hasil penelitian sebelumnya yang dilakukan oleh (Aziz, 2016) dalam jurnal yang berjudul "Pengaruh Motivasi Kerja, Disiplin Kerja dan Lingkungan Kerja Terhadap Kinerja Melalui Kepuasan Kerja Pada Pegawai Puskesmas Kecamatan Balapulang Kabupaten Tegal” menunjukkan bahwa variabel disiplin kerja berpengaruh signifikan terhadap kinerja karyawan. Kehadiran yang tepat waktu merupakan hal yang sangat penting peranannya dan sangat dibutuhkan untuk meningkatkan kinerja karyawan.

3. Pengaruh Motivasi Kerja $\left(\mathrm{X}_{1}\right)$ dan Disiplin Kerja $\left(\mathrm{X}_{2}\right)$ secara Simultan terhadap Kinerja Karyawan (Y) PT. Pegadaian Cabang Nganjuk

Berdasarkan uji $\mathrm{F}$, hasil $\mathrm{F}$ hitung menunjukkan nilai 13,532 > $\mathrm{F}$ tabel yaitu 3,32 maka terdapat pengaruh secara simultan variabel motivasi kerja dan disiplin kerja terhadap kinerja karyawan pada PT. Pegadaian Cabang Nganjuk. 
Hasil penelitian ini selaras dengan hasil penelitian sebelumnya yang dilakukan oleh (Widyaningtyas, 2016) dalam skripsi yang berjudul "Pengaruh Disiplin Kerja dan Motivasi Kerja Terhadap Kinerja Karyawan (Studi pada PT. Macanan Jaya Cemerlang Klaten)" yang menyatakan bahwa motivasi kerja dan disiplin kerja secara simultan berpengaruh terhadap kinerja karyawan. Menurut Bangun (2012:230), peningkatan kinerja merupakan hal yang diinginkan baik dari pihak pemberi kerja maupun para pekerja. Pemberi kerja menginginkan kinerja karyawannya baik untuk kepentingan peningkatan hasil kerja dan keuntungan perusahaan. Disisi lain, para pekerja berkepentingan untuk pengembangan diri dan promosi pekerjaan.

\section{KESIMPULAN DAN SARAN}

\section{Kesimpulan}

Berdasarkan hasil penelitian yang dilakukan oleh peniliti dengan judul "Pengaruh Motivasi Kerja dan Disiplin Kerja Terhadap Kinerja Karyawan Pada PT. Pegadaian (Persero) Cabang Nganjuk" maka dapat ditarik kesimpulan sebagai berikut:

1. Motivasi Kerja $\left(\mathrm{X}_{1}\right)$

Hasil statistik uji t untuk variabel motivasi kerja diketahui bahwa nilai $\mathrm{t}$ hitung sebesar 5,043 $>\mathrm{t}$ tabel sebesar 2,756 dengan nilai signifikan $0,000<0,01$. Maka secara parsial terdapat pengaruh yang signifikan antara variabel motivasi kerja terhadap variabel kinerja karyawan.

2. Disiplin Kerja $\left(\mathrm{X}_{2}\right)$

Hasil statistik uji t untuk variabel disiplin kerja diketahui bahwa nilai $\mathrm{t}$ hitung sebesar $0,157<$ nilai $t$ tabel adalah 2,756 dengan nilai signifikan 0,876>0,01. Maka secara parsial tidak ada pengaruh signifikan antara variabel disiplin kerja terhadap variabel kinerja karyawan.

3. Motivasi Kerja $\left(\mathrm{X}_{1}\right)$ dan Disiplin Kerja $\left(\mathrm{X}_{2}\right)$

Hasil statistik uji F untuk variabel motivasi kerja dan disiplin kerja diketahui bahwa nilai $\mathrm{F}$ hitung sebesar $13,532>\mathrm{F}$ tabel yaitu 3,32. Maka terdapat pengaruh secara simultan antara motivasi kerja dan disiplin kerja terhadap kinerja karyawan PT. Pegadaian (Persero) Cabang Nganjuk. 
4. Kontribusi motivasi kerja dan disiplin kerja untuk menjelaskan kinerja karyawan sebesar 0, 483 atau 48,3\% sedangkan 51,7\% dijelaskan oleh variabel lain di luar penelitian.

\section{Saran}

Berdasarkan hasil analisis pembahasan serta beberapa kesimpulan pada penelitian ini, saran-saran yang dapat diberikan melalui hasil penelitian ini, yaitu:

1. Bagi lembaga, agar tetap meningkatkan motivasi kerja dan disiplin kerja karena baik motivasi kerja maupun disiplin kerja berpengaruh signifikan terhadap kinerja karyawan.

2. Diharapkan hasil penelitian ini dapat dipakai sebagai acuan bagi peneliti selanjutnya. Selain itu, pada penelitian selanjutnya juga perlu pengembangan pendekatan dan variabel yang berbeda untuk melihat kinerja karyawan.

\section{DAFTAR PUSTAKA}

Gifari. (2010). Analisis Regresi Teori, Kasus dan Sosial Edisi Kedua. Yogyakarta: BPFE.

Arikunto, S. (2010). Prosedur Penelitian Suatu Pendekatan Praktik. Jakarta: Rineka Cipta.

Ashadi, A. K. (2011). Pengaruh Motivasi Kerja dan Disiplin Kerja Terhadap Kinerja Karyawan Bagian Produksi Pada Perusahaan Daerah Air Minum (PDAM) Tirta Moedal Kota Semarang.

Hartanti, Y. (2016). Pengaruh Motivasi Terhadap Prestasi Kerja Karyawan Pada PT.Pegadaian Syariah Cabang Palembang.

Mariani, L. M. I. (2016). Pengaruh Motivasi, Komunikasi dan Disiplin Kerja Terhadap Kinerja Karyawan Warung Mina Peguyangan di Denpasar.

Rahayu, B., \& Ruhamak, M. D. (2018). Pengaruh Kepemimpinan, Insentif, Remunerasi Dan Motivasi Terhadap Kinerja Karyawan (Studi Kasus Pada Pt Industri Sandang Pangan Nusantara Cilacap). Ekonika : Jurnal Ekonomi Universitas Kadiri, 2(1), 122. https://doi.org/10.30737/ekonika.v2i1.15

Widayaningtyas, R. (2016). Pengaruh Disiplin Kerja dan Motivasi Kerja Terhadap Kinerja Karyawan (Studi pada PT. Macanan Jaya Cemerlang Klaten).

Wijaya, A. T. (2016). Analisis Pengaruh Lingkungan Kerja dan Motivasi Kerja Terhadap Kinerja Karyawan Pada PT. Pegadaian Cabang Jember.

Yogi yunanto, sasi utami. (2017). Pengaruh motivasi dan kepuasan kerja terhadap prestasi kerja dosen universitas kadiri. Ekonika, pp. 99-110.

Yunanto, Y. (2016). ANALISIS PENGARUH KUALITAS PELAYANAN DAN DISIPLIN KERJA KARYAWAN TERHADAP KEPUASAN PASIEN ASKES DI 
JIMEK - Volume 2 Nomor 1 Juli 2019

Pengaruh Motivasi Kerja...... (Arisanti, dkk)

Doi :

ISSN : 2621-2374

PT ASKES KEDIRI. Jurnal Ekonomi Universitas Kadiri, 1(1), 26-37.

https://id.wikipedia.org/wiki/Pegadaian_(perusahaan)

https://www.pegadaian.co.id/profil/visi-dan-misi 